\title{
Effect of soy flour addition on sensory quality of extrusion and conventionally cooked cassava complementary porridges
}

\author{
Penina N. Muoki ${ }^{1,2}$, Marise Kinnear ${ }^{1}$, Mohammad Naushad Emmambux ${ }^{1}$ and Henriëtte L. de \\ $\operatorname{Kock}^{1 *}$ \\ ${ }^{1}$ Department of Food Science, University of Pretoria, Private bag X20, Hatfield 0028, South Africa \\ ${ }^{2}$ International Institute of Tropical Agriculture, 709 Nampula, Mozambique \\ Email address of corresponding author: riette.dekock@up.ac.za
}

Running title: Sensory quality of extrusion and conventionally cooked cassava-soy complementary porridges

\begin{abstract}
BACKGROUND: The sensory properties of the usual conventionally cooked cassava porridge consumed in some regions of Africa and porridges consisting of ccomposited cassava and either defatted or full fat soy flour, with or without extrusion cooking, were evaluated to better understand consumers' acceptance. The composited and extruded porridges have superior nutritional quality and added convenience value in the case of extrusion cooked products.
\end{abstract}

RESULTS: Extrusion cooking allowed preparation of porridges with $25 \%$ solids content (compared to $10 \%$ for conventional cooking) with a viscosity suitable for consumption by infants. Compositing and extrusion cooking reduced the apparent negative sensory attributes of high viscosity, stickiness, translucency, jelly-like appearance and bland flavour that characterize conventionally cooked cassava porridge while increasing slimy appearance of the porridge. The caramel aroma and overall flavour of all extrusion cooked porridges was more intense, with more toasted nutty flavour and aftertaste compared to the corresponding 
conventionally cooked porridges. Slightly more consumers preferred the conventionally cooked cassava-soy flour porridges.

CONCLUSIONS: Compositing cassava flour with fullfat or defatted soy flour and extrusion cooking change the appearance and flavour of porridges while improving the textural properties for better mastication and swallowing by infants. Hedonic adjustment to the changed sensory properties of the porridges in comparison to what mothers and caregivers are used to (conventionally cooked cassava only porridges) is required to ensure acceptance.

Key words: Cassava-soy, complementary porridge, conventionally cooked, extrusion, sensory quality

\section{INTRODUCTION}

Recently, Muoki et al. ${ }^{1}$ demonstrated that compositing cassava and soy flour (either defatted or full fat) and extrusion cooking can be used to produce ready-to-eat complementary porridges that have superior nutritional quality compared to the usual cassava porridges consumed in some regions of Africa. In addition, compositing and the heat processing method applied, influenced mothers/caregivers liking of cassava-soy flour porridges. To further understand the determinants of consumer acceptance of these porridges, sensory profiling is crucial.

In sub-Saharan Africa, cassava is principally prepared as traditional foods that are consumed mainly within producing countries such as Nigeria, Tanzania and Mozambique ${ }^{2,3}$. Conventionally cooked traditional cassava based foods, for example fufu and agbelima (types of stiff porridge), are perceived as sticky (cohesive) a sensory characteristic that is not favoured beyond cassava producing countries ${ }^{4}$. 
Cassava flour contains about $80 \% \operatorname{starch}^{5}$. Cassava has a neutral flavour ${ }^{6}$ and bland taste that has been attributed to limited lipid content ${ }^{7}$. In addition, compared to the viscosity of maize porridge, cassava porridge has higher viscosity ${ }^{8}$ due to the high swelling power of its biomolecules ${ }^{9}$. Highly viscous porridges are not desirable for complementary feeding. Cassava porridge is not the preferred choice for complementary porridges in part due to their cohesive nature and low nutrient content. Infants cannot handle porridges of a viscosity higher than $3000 \mathrm{cP}$. Sticky porridges pose an eating challenge due to the physically underdeveloped motor function of infants' tongue. At 6 months, infants can only move their tongue laterally when food is put in their mouths, by 8 months the tongue can move from the centre of the mouth to the sides. After 2 years, the tongue is able to make a smooth midline transfer of a food bolus ${ }^{11}$. Thus, processing procedures that can reduce these apparently negative sensory attributes (high viscosity, stickiness) are likely to increase utilization of cassava as complementary food.

Extrusion of a mixture of starch, protein and oil may result in development of colour, flavour and aroma compounds ${ }^{12,13}$. This is probably due to the occurrence of Maillard reaction between the free $\varepsilon$-amino groups of lysine and carbonyl groups. Pyrazines are some of the major classes of volatiles identified in extrudates with roasted and nutty properties ${ }^{14}$. Furans are oxygen containing heterocyclics that provide a sweet or caramel-like aroma and may be formed from pyrolysis of sugars during extrusion ${ }^{15}$. Compositing cassava flour with full fat soy flour or defatted soy flour and soy oil increase the lipid content of the porridge. Food matrixes containing lipids may exude more flavour as lipids act as flavour carriers. ${ }^{16}$

No information on sensory profiling of either conventionally cooked or extrusion cooked cassava-soy complementary porridges could be found. Information on how the sensory 
properties influence consumer liking of porridge is also not available. Muoki et al. ${ }^{1}$ previously reported consumer acceptability of colour, aroma, taste and overall acceptability of extrusion and conventionally cooked cassava-soy flour complementary porridges. In this publication, the relationship between overall acceptability ratings and descriptive sensory profiles of the porridges were explored. Thus, the objectives of this study were to determine the sensory profiles of conventionally cooked cassava and cassava-soy complementary porridges (10\% solids) and also of extrusion cooked cassava and cassava-soy porridges (with $25 \%$ solids). Muoki et al. ${ }^{1}$ previously reported results for acceptability of colour, aroma, taste and overall acceptability of the porridges. In this paper the relationship between overall acceptability ratings and descriptive sensory profiles of the porridges was explored.

\section{MATERIALS AND METHODS}

In this study, addition of soy (cassava only, with full fat or with defatted soy); cooking process (conventional cooking or extrusion cooking) and solids content of porridge (10\% or $25 \%$ ) were experimental variables. However, while extrusion cooking allows the inclusion of $25 \%$ solids, $10 \%$ solids is the limit for conventionally cooked porridges. For this reason a fractional (at the level of solids content) factorial experimental design was used to accommodate the limitation of too high viscosity but ensuring optimum nutrient density of porridge for infant feeding.

\section{Materials}

The raw materials were formulated as described by Muoki et al. ${ }^{1}$. Briefly, porridge formulations were based on dry weight as follows: (1) 100\% cassava flour (control) (2) $65 \%$ cassava flour and 35\% defatted toasted soy flour (3) 65\% cassava flour, $28 \%$ defatted toasted 
soy flour and $7 \%$ soy oil. To formulate a composite of cassava-full fat soy flour, addition of soy oil to defatted toasted soy flour to simulate full fat soy flour was selected to avoid variations in protein configuration. This is because the commercial preparation of defatted soy flour differs from the preparation of full fat soy flour in that it involves additional steps of flaking, solvent extraction and desolvenizing ${ }^{17}$. Mustakas et al ${ }^{17}$ found these steps to reduce the protein solubility index and trypsin inhibitor content by $27 \%$ and $19 \%$, respectively. Trypsin inhibitor was present at $1.5 \pm 0.3$ trypsin inhibitor units in the defatted soy flour as determined using AACC method 22-40 ${ }^{18}$. The common method of preparing cassava flour was followed ${ }^{19}$. The total cyanide and acetone cyanohydrin contents determined according to the method described by Bradbury ${ }^{20}$ were $5.6 \pm 0.2$ and $2.7 \pm 0.7 \mathrm{mg} \mathrm{kg}^{-1}$ respectively, both below the safe level ${ }^{21}$ of $10 \mathrm{mg} \mathrm{kg-1}$.

\section{Methods}

\section{a) Conventional cooking}

Conventionally cooked porridges were prepared using the three formulations as described by

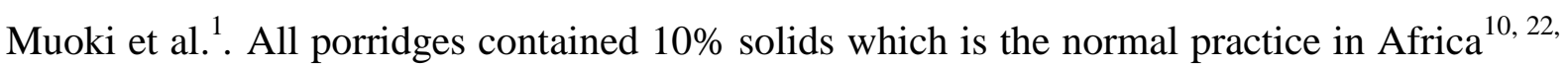
23.

\section{b) Extrusion cooking}

Extrusion cooked porridges were prepared using the three formulations as described by Muoki et al. ${ }^{1}$. In brief, a Clextral BC 45 co-rotating twin screw extruder (Clextral Firminy, France) at a screw speed of $200 \mathrm{rpm}$, a barrel temperature of $120^{\circ} \mathrm{C}$ and a retention time of 2 minutes was used. Preparation of the extrusion cooked porridges involved mixing the flour with boiled hot water (1:3). All extrusion cooked porridges contained $25 \%$ solids. This solids content was based on that of a commercial ready-to-eat porridge. 


\section{Determination of porridge viscosity}

A rotational concentric cylinder rheometer (Physica MCR 301, Anton Paar, GmbH, Ostfildern, Germany) with temperature control and data acquisition software (Rheoplus version 3) was used to determine the viscosity of porridges. Immediately after preparation, porridges were cautiously transferred into the rheometer cup maintained at $40{ }^{\circ} \mathrm{C}$ and then left to equilibrate for approximately $10 \mathrm{~min}$. A thin layer of light paraffin oil was applied on top of the exposed sample surface to prevent loss of moisture through evaporation ${ }^{24}$. After equilibration, the apparent viscosity was recorded at $100 \mathrm{~s}^{-1}$ to resemble the maximum shear developed in a human's mouth during mastication of pastes/porridges of a viscosity between 100 to $100000 \mathrm{cP}^{25}$. Three independent measurements were taken.

\section{Determination of textural properties}

The textural properties (firmness and stickiness) were determined using a TA-XT2 Texture Analyzer (Stable Micro Systems, Godalming, UK). Using the following conditions: force in compression; pre-test speed $2.0 \mathrm{~mm} \mathrm{~s}^{-1}$; test speed $0.5 \mathrm{mms}^{-1}$; post-test speed $0.5 \mathrm{~mm} \mathrm{~s}^{-1}$; sample penetration distance $5.0 \mathrm{~mm}$; using a $20 \mathrm{~mm}$ flat cylindrical perspex probe. Porridges were allowed to cool to $40{ }^{\circ} \mathrm{C}$ in a beaker covered with aluminium foil. The surface layer of the porridge was cautiously scraped off prior to analysis. Firmness was the maximum force registered as the probe penetrated the porridge while stickiness was the maximum (negative force) obtained as the probe withdrew from the porridge ${ }^{26}$. Three independent measurements were taken.

\section{Descriptive sensory evaluation}

Ethical approval for sensory and consumer evaluation as described for the study was granted by the Faculty of Natural and Agricultural Sciences, University of Pretoria, South Africa. 
Table 1: Sensory descriptors, evaluation guidelines and consensus values for references used by sensory panel to evaluate cassava-soy porridges

\begin{tabular}{|c|c|c|c|}
\hline Descriptor & Definition & Rating scale & References \\
\hline \multicolumn{4}{|l|}{ Appearance } \\
\hline Glossy & $\begin{array}{l}\text { Hold the cup bent in the direction of light. The amount of shine or gloss } \\
\text { perceived on the surface of the product }\end{array}$ & $\begin{array}{l}\text { Not Glossy }=0 \\
\text { Very Glossy }=9\end{array}$ & $\begin{array}{l}\text { Crosse } \& \text { Blackwell light mayonnaise }=5 \\
\text { Fleures pure honey }=9\end{array}$ \\
\hline Jelly-like & $\begin{array}{l}\text { Hold the cup bent in the direction of light and shake gently. Product's ability } \\
\text { to wiggle similar to gelatine dessert/ visual evaluation of gel-like appearance of } \\
\text { the porridge. }\end{array}$ & $\begin{array}{l}\text { Not jelly-like }=0 \\
\text { Very jelly-like }=9\end{array}$ & $\begin{array}{l}\text { Moir's Jelly prepared as per manufacturer's } \\
\text { instruction }=9\end{array}$ \\
\hline Sticky & $\begin{array}{l}\text { Use the back of the spoon to pull the porridge from the sides of the bowl. The } \\
\text { degree to which a spoon adheres to the product }\end{array}$ & $\begin{array}{l}\text { Not sticky }=0 \\
\text { Very sticky }=9\end{array}$ & Johnson's baby oil $=0$ \\
\hline Viscosity & Stir the porridge in a clockwise manner once. Note the resistance to flow. & $\begin{array}{l}\text { Not viscous }=0 \\
\text { Very viscous }=9\end{array}$ & $\begin{array}{l}\text { Filtered water }=1 \\
\text { Hulett's chocolate syrup }=9\end{array}$ \\
\hline Translucency & The degree to which a product looks translucent when poured from a spoon & $\begin{array}{l}\text { Not translucent }=0 \\
\text { Very translucent }=9\end{array}$ & Pick 'n Pay smooth Apricot jam $=9$ \\
\hline Slimy & Degree of cohesiveness as porridge flows from a spoon & $\begin{array}{l}\text { Not slimy }=0 \\
\text { Very slimy }=9\end{array}$ & $\begin{array}{l}\text { Hulett's chocolate syrup }=5 \\
\text { Hulett's smooth toffee sauce }=9\end{array}$ \\
\hline Smooth & Product's evenness, absence of lumps or clumps & $\begin{array}{l}\text { Not smooth }=0 \\
\text { Very smooth }=9\end{array}$ & Danone smooth yoghurt $=9$ \\
\hline \multicolumn{4}{|l|}{ Aroma } \\
\hline Starchy & Aroma associated with undercooked maize porridge & $\begin{array}{l}\text { Not intense }=0 \\
\text { Very intense }=9\end{array}$ & $\begin{array}{l}35 \% \text { ACE maize flour stirred in boiled } \\
\text { water without further cooking }=9\end{array}$ \\
\hline Caramel & Aroma associated with toasted and browned sugar without burning it & $\begin{array}{l}\text { No intense }=0 \\
\text { Very intense }=9\end{array}$ & Hulett's caramel sauce $=9$ \\
\hline Toasted nutty & Aroma associated with toasted peanuts & $\begin{array}{l}\text { Not intense }=0 \\
\text { Very intense }=9\end{array}$ & \\
\hline Sweet & Sweet aromatics associated with boiled herbal tea & $\begin{array}{l}\text { Not intense }=0 \\
\text { Very intense }=9\end{array}$ & Boiled Black Forest herbal tea $=9$ \\
\hline Beany & Aroma associated with undercooked legumes & $\begin{array}{l}\text { Not intense }=0 \\
\text { Very intense }=9\end{array}$ & Soybeans soaked in water overnight $=9$ \\
\hline Wet bran & Aromatics associated with wetted bran & $\begin{array}{l}\text { Not intense }=0 \\
\text { Very intense }=9\end{array}$ & Pick ' $n$ Pay Oat bran, wetted $=9$ \\
\hline
\end{tabular}


Flavour (swirl 1/2 teaspoonful of sample around the mouth before swallowing)

\begin{tabular}{|c|c|c|c|}
\hline Cooked soy & Flavour associated with cooked soy flour & $\begin{array}{l}\text { Not intense }=0 \\
\text { Very intense }=9\end{array}$ & $\begin{array}{l}35 \% \text { defatted toasted soy flour in boiled } \\
\text { water }=9\end{array}$ \\
\hline Toasted nutty & Flavour associated with toasted nuts & $\begin{array}{l}\text { Not intense }=0 \\
\text { Very intense }=9\end{array}$ & \\
\hline Overall flavour & Overall intensity of flavour sensation & $\begin{array}{l}\text { Not intense/bland }=0 \\
\text { Very intense }=9\end{array}$ & Thin ACE maize porridge $(10 \%$ solids $)=5$ \\
\hline Starchy & Flavour associated with undercooked maize porridge & $\begin{array}{l}\text { Not intense }=0 \\
\text { Very intense }=9\end{array}$ & $\begin{array}{l}35 \% \text { ACE maize flour paste in boiled water } \\
\text { without further heating }=9\end{array}$ \\
\hline Sour taste & Fundamental taste sensation elicited by acids & $\begin{array}{l}\text { Not intense }=0 \\
\text { Very intense }=9\end{array}$ & $9 \% \mathrm{w} / \mathrm{v}$ tartaric acid in water $=9$ \\
\hline Dense & The degree to which food feels heavy in the mouth and does not move easily & $\begin{array}{l}\text { Not intense }=0 \\
\text { Very intense }=9\end{array}$ & \\
\hline Mealy & $\begin{array}{l}\text { The perception of fine, soft, somewhat round and smooth particles evenly } \\
\text { distributed within the product }\end{array}$ & $\begin{array}{l}\text { Not mealy- } 0 \\
\text { Very mealy- } 9\end{array}$ & $\begin{array}{l}\text { Iwisa stiff maize flour porridge ( } 35 \% \text { flour } \\
\text { in water) }=5\end{array}$ \\
\hline \multicolumn{4}{|l|}{ After swallowing } \\
\hline Grainy & $\begin{array}{l}\text { The degree to which food leaves residual grainy particles in the mouth after } \\
\text { swallowing }\end{array}$ & $\begin{array}{c}\text { No particles }=0 \\
\text { Many particles }=9\end{array}$ & $\begin{array}{l}\text { Iwisa stiff maize porridge ( } 35 \% \text { flour in } \\
\text { water) }=5\end{array}$ \\
\hline $\begin{array}{l}\text { Oily mouth } \\
\text { coating }\end{array}$ & Feeling that the palate is coated with a fatty or starchy film & $\begin{array}{l}\text { Not oily }=0 \\
\text { Very oily }=9\end{array}$ & \\
\hline Starchy & Intensity of aftertaste associated with undercooked maize porridge & $\begin{array}{l}\text { Not intense }=0 \\
\text { Very intense }=9\end{array}$ & \\
\hline Bitter & Intensity of a lingering bitter aftertaste & $\begin{array}{l}\text { Not intense }=0 \\
\text { Very intense }=9\end{array}$ & \\
\hline Cooked soy & Intensity of aftertaste associated with cooked soybean flour & $\begin{array}{l}\text { Not intense }=0 \\
\text { Very intense }=9\end{array}$ & $\begin{array}{l}35 \% \text { defatted toasted soy flour in boiled } \\
\text { water }=9\end{array}$ \\
\hline
\end{tabular}




\section{a) Panel training}

The generic descriptive sensory method of Einstein $^{27}$ was used. Ten sessions of $2 \mathrm{~h}$ each were devoted to training and discussions to attain consensus on sensory descriptors and evaluation scales (Table 1).

\section{b) Sample presentation and assessment}

Nine female students (20-38 years) participated in the study. The panel entered data directly on computer (Compusense Five ${ }^{\circledR}$ Release 4.6 Compusense Inc, Guelph, Canada). Porridge ( $40 \mathrm{~g})$ in glass ramekins was evaluated using stainless steel spoons. Carrot rings and filtered tap water at room temperature $\left(\sim 25^{\circ} \mathrm{C}\right)$ were used for rinsing the mouth before and between samples. Each panellist evaluated six porridges within a $1 \mathrm{~h}$ session. To avoid fatigue, porridges were served in two sets of three with a delay of 10 min between the two sets. The order of sample presentation was followed the Williams Latin square design. Evaluation of the porridges was done in triplicate over three days giving 27 data points per porridge. Ratings for individual samples were averaged over 9 panellists.

\section{Consumer sensory evaluation}

Consumer sensory evaluation with mothers/caregivers $(n=122)$ with children aged below 2 years was done as described by Muoki et al. ${ }^{1}$. Consumers expressed their liking of different attributes and overall acceptability using 5-point hedonic scales $(1=$ Dislike very much, $2=$ Dislike moderately, 3 = Neither like nor dislike, $4=$ Like moderately, $5=$ Like very much).

\section{Statistical analysis}

Mean descriptive panel ratings, instrumental viscosity, and textural measurements (dependent variables) were subjected to analysis of variance (ANOVA) with porridge type as the independent variable. Porridges prepared using conventional cooking had lower solids contents $(10 \%)$ compared to those prepared by extrusion cooking $(25 \%)$. For this reason, 
separate analyses were conducted for the two cooking methods. Fischer's least significant difference (LSD) test was used to separate means using Statistica software version 10.0 (StatSoft, Tulsa, OK) at $\mathrm{p}<0.05$. Unscrambler ${ }^{\circledR} \mathrm{X}$, version 10.1 (CAMO Software AS., Nedre Vollgate 8 N-0158, Oslo Norway) was used to establish interrelationships between descriptive sensory attributes and consumer overall acceptability of the porridges. Sensory attributes were treated as the $\mathrm{X}$-variables while consumer scores were $\mathrm{Y}$-variables. Consumer data were also related to the descriptive sensory attributes using the external preference mapping technique (PREFMAP, XLSTAT-MX, Addinsoft, Anglesey, UK). Agglomerative hierarchical clustering (AHC, Ward's criterion) was performed in order to group consumers with similar liking profiles in a multidimensional space. Cluster preferences were then regressed onto the first two principal components of the PCA of the descriptive sensory data.

\section{RESULTS}

\section{Viscosity and textural properties}

Table 2 shows the viscosity and textural properties of cassava-soy flour porridges. Conventionally cooked porridges with defatted soy flour and with full fat soy flour were much less viscous compared to conventionally cooked cassava porridge. On the contrary, extrusion cooked porridge with soy flour were more viscous $(\mathrm{p}<0.05)$ compared to extrusion cooked cassava porridge. While within the acceptable viscosity range for infant feeding, extrusion cooked porridge with full fat soy flour, at $25 \%$ solids content, had the highest viscosity.

For extrusion cooked porridges, the porridge with defatted soy flour was most firm and sticky while for conventionally cooked porridges; cassava porridge was most firm and sticky (Table 
Table 2: Effect of soy flour addition on values of shear viscosity and textural properties (firmness and stickiness) of cassava complementary porridges at $40^{\circ} \mathrm{C}$

Values are means of three independent analyses \pm standard deviation.

\begin{tabular}{lllll}
\hline Cooking method & Type of porridge & Viscosity $(\mathrm{cP})$ & & Texture \\
& & & Firmness (N) & Stickiness (N) \\
\hline Conventional & Cassava & $1.7^{\mathrm{b}} \pm 0.10$ & $0.29^{\mathrm{b}} \pm 0.00$ & $-0.14^{\mathrm{c}} \pm 0.00$ \\
$(10 \%$ solids) & With defatted soy & $0.7^{\mathrm{a}} \pm 0.02$ & $0.13^{\mathrm{a}} \pm 0.00$ & $-0.05^{\mathrm{a}} \pm 0.00$ \\
& With full fat soy & $0.7^{\mathrm{a}} \pm 0.17$ & $0.19^{\mathrm{a}} \pm 0.00$ & $-0.08^{\mathrm{b}} \pm 0.00$ \\
& & & & \\
Extrusion cooked & Cassava & $1.5^{\mathrm{a}} \pm 0.35$ & $0.10^{\mathrm{a}} \pm 0.03$ & $-0.05^{\mathrm{a}} \pm 0.03$ \\
$(25 \%$ solids $)$ & With defatted soy & $2.2^{\mathrm{b}} \pm 0.20$ & $0.12^{\mathrm{b}} \pm 0.03$ & $-0.07^{\mathrm{b}} \pm 0.01$ \\
& With full fat soy & $2.8^{\mathrm{c}} \pm 0.22$ & $0.08^{\mathrm{a}} \pm 0.02$ & $-0.03^{\mathrm{a}} \pm 0.02$
\end{tabular}

Values in the same column (for a cooking method) followed by the same letter are not significantly different (p $<0.05)$

Cassava $-100 \%$ cassava flour

With defatted soy flour $-65 \%$ cassava flour and $35 \%$ defatted soy flour

With full fat soy flour-65\% Cassava flour, $28 \%$ defatted soy flour and $7 \%$ soy oil

2). There was no significant difference in firmness between conventionally cooked porridges with defatted and with full fat soy flour. Addition of soy flour significantly reduced stickiness in conventionally cooked. Full fat soy flour did not change stickiness for extrusion cooked porridge.

\section{Descriptive sensory evaluation}

Table 3 shows the ratings for sensory attributes of conventionally cooked porridges. Addition of soy flour made these porridges less translucent and jelly-like, less sticky and viscous but more slimy. Starchy aroma was a prominent attribute for all three porridges but it was most intense in cassava only porridge. In terms of flavour, addition of soy flour increased the toasted nutty flavour and toasted aftertaste, cooked soy flavour and overall flavour intensity compared to cassava porridge. 
Table 3: Effect of adding soy flour on descriptive sensory ratings of conventionally cooked cassava porridges (10\% solids)

\begin{tabular}{|c|c|c|c|c|}
\hline & Sensory attribute & Cassava & With defatted soy & With full fat soy \\
\hline \multirow[t]{7}{*}{ Appearance } & Glossiness & $6.3^{b} \pm 0.9$ & $6.2^{\mathrm{b}} \pm 1.0$ & $5.6^{\mathrm{a}} \pm 1.0$ \\
\hline & Jelly-like & $6.4^{\mathrm{c}} \pm 0.7$ & $4.3^{b} \pm 1.3$ & $3.6^{\mathrm{a}} \pm 1.2$ \\
\hline & Stickiness & $5.1^{\mathrm{b}} \pm 1.8$ & $3.3^{\mathrm{a}} \pm 1.1$ & $3.4^{\mathrm{a}} \pm 1.0$ \\
\hline & Viscosity & $6.6^{b} \pm 0.6$ & $4.6^{\mathrm{a}} \pm 1.0$ & $4.6^{\mathrm{a}} \pm 1.1$ \\
\hline & Translucent & $5.9^{b} \pm 1.0$ & $4.0^{\mathrm{a}} \pm 1.1$ & $3.4^{\mathrm{a}} \pm 1.0$ \\
\hline & Sliminess & $2.3^{\mathrm{a}} \pm 1.0$ & $3.6^{b} \pm 0.9$ & $2.8^{a} \pm 0.8$ \\
\hline & Smoothness & $4.7 \pm 1.9$ & $5.3 \pm 1.3$ & $5.1 \pm 1.3$ \\
\hline \multirow[t]{7}{*}{ Aroma } & Starchy & $5.8 \pm 1.5$ & $5.1 \pm 1.4$ & $5.1 \pm 1.4$ \\
\hline & Caramel & $2.4 \pm 1.1$ & $2.7 \pm 1.2$ & $3.0 \pm 1.2$ \\
\hline & Toasted nutty & $1.9^{\mathrm{a}} \pm 0.8$ & $3.0^{\mathrm{b}} \pm 1.4$ & $3.2^{\mathrm{b}} \pm 1.5$ \\
\hline & Sweet & $3.5 \pm 1.3$ & $3.0 \pm 1.3$ & $3.1 \pm 1.4$ \\
\hline & Beany & $1.6^{a} \pm 0.9$ & $2.3^{\mathrm{ab}} \pm 1.3$ & $2.5^{\mathrm{b}} \pm 1.5$ \\
\hline & Bran & $2.8 \pm 1.1$ & $3.0 \pm 1.1$ & $2.7 \pm 1.2$ \\
\hline & Dry grass/hay & $2.6 \pm 1.0$ & $2.9 \pm 1.1$ & $2.7 \pm 1.2$ \\
\hline \multirow[t]{5}{*}{ Flavour } & Cooked soy flour & $2.4^{\mathrm{a}} \pm 1.3$ & $3.3^{b} \pm 1.4$ & $4.1^{c} \pm 1.3$ \\
\hline & Toasted nutty & $2.3 \pm 1.5$ & $3.2 \pm 1.4$ & $3.2 \pm 1.5$ \\
\hline & Overall flavour & $3.4 \pm 1.2$ & $3.6 \pm 1.1$ & $4.1 \pm 1.1$ \\
\hline & Starchy & $1.6 \pm 1.3$ & $2.0 \pm 1.2$ & $2.4 \pm 1.3$ \\
\hline & Sour & $1.1 \pm 0.6$ & $1.4 \pm 0.9$ & $1.2 \pm 0.8$ \\
\hline \multirow[t]{3}{*}{ Mouthfeel } & Denseness & $3.3 \pm 1.7$ & $2.6 \pm 1.1$ & $2.7 \pm 1.1$ \\
\hline & Mealiness & $3.8^{a} \pm 1.5$ & $4.7^{\mathrm{b}} \pm 1.1$ & $4.9^{b} \pm 1.3$ \\
\hline & Grainy & $4.9 \pm 1.3$ & $4.5 \pm 1.4$ & $4.4 \pm 1.2$ \\
\hline \multirow[t]{3}{*}{ Post swallowing sensation } & Oily mouth coating & $1.9 \pm 0.8$ & $2.2 \pm 0.9$ & $2.4 \pm 1.3$ \\
\hline & Starchy aftertaste & $4.6 \pm 1.5$ & $4.5 \pm 1.7$ & $4.5 \pm 1.3$ \\
\hline & $\begin{array}{l}\text { Cooked soy aftertaste } \\
\text { Bitter aftertaste }\end{array}$ & $\begin{array}{c}2.1 \pm 1.3 \\
\mathbf{1 . 4}^{\mathrm{a}} \pm \mathbf{1 . 2}\end{array}$ & $\begin{array}{c}2.6 \pm 1.5 \\
\mathbf{2 . 0} \mathbf{0}^{\mathrm{ab}} \pm \mathbf{1 . 3}\end{array}$ & $\begin{array}{r}2.8 \pm 1.6 \\
\mathbf{2 . 3}^{\mathbf{b}} \pm \mathbf{1 . 4}\end{array}$ \\
\hline
\end{tabular}

Values are mean ratings for a trained panel $(\mathrm{n}=9) \pm$ standard deviation. Values within the same row followed by the same letter are not significantly different $(\mathrm{p}<0.05)$. Attributes indicated significant difference shown in bold.

Cassava $=100 \%$ cassava flour, With defatted soy flour $=65 \%$ cassava flour and $35 \%$ defatted soy flour, With full fat soy flour $=65 \%$ Cassava flour, $28 \%$ defatted soy flour and $7 \%$ soy oil The lowest value was 0 , indicating not viscous, not glossy, not translucent, not jelly, not slimy, not oily, and not intense; The highest score was 9 indicating very glossy, very jelly-like, very sticky, very translucent, very oily, very slimy very many and very intense

${ }^{1}$ Definitions of attributes are available in Table 1. 
Table 4: Effect of soy flour addition on descriptive sensory ratings for extrusion cooked cassava complementary porridges (25\% solids)

\begin{tabular}{|c|c|c|c|c|}
\hline & Sensory attribute & Cassava & With defatted soy & With full fat soy \\
\hline \multirow[t]{7}{*}{ Appearance } & Glossiness & $6.1 \pm 1.2$ & $6.4 \pm 1.0$ & $5.9 \pm 1.0$ \\
\hline & Jelly-like & $2.0 \pm 1.1$ & $1.4 \pm 0.9$ & $1.6 \pm 0.9$ \\
\hline & Stickiness & $3.9 \pm 1.5$ & $3.4 \pm 1.3$ & $3.7 \pm 1.4$ \\
\hline & Viscosity & $3.8 \pm 1.3$ & $3.6 \pm 0.9$ & $3.3 \pm 1.1$ \\
\hline & Translucent & $2.6^{b} \pm 0.9$ & $1.2^{\mathrm{a}} \pm 0.7$ & $1.5^{\mathrm{a}} \pm 0.9$ \\
\hline & Slimy/soapy & $6.4 \pm 1.3$ & $6.5 \pm 1.1$ & $6.5 \pm 1.1$ \\
\hline & Smoothness & $6.9 \pm 0.9$ & $6.8 \pm 1.0$ & $6.8 \pm 0.9$ \\
\hline \multirow[t]{7}{*}{ Aroma } & Starchy & $4.2 \pm 1.3$ & $4.1 \pm 1.0$ & $4.1 \pm 1.4$ \\
\hline & Caramel & $4.2 \pm 1.3$ & $4.4 \pm 1.5$ & $4.2 \pm 1.5$ \\
\hline & Toasted nutty & $4.4 \pm 1.6$ & $5.4 \pm 1.4$ & $4.9 \pm 1.6$ \\
\hline & Sweet & $4.2 \pm 1.5$ & $3.9 \pm 1.9$ & $4.1 \pm 1.5$ \\
\hline & Beany & $2.4 \pm 1.6$ & $2.8 \pm 1.6$ & $2.7 \pm 1.3$ \\
\hline & Bran & $2.6 \pm 1.4$ & $2.9 \pm 1.4$ & $2.8 \pm 1.4$ \\
\hline & Dry grass/hay & $2.2 \pm 1.2$ & $2.2 \pm 1.1$ & $2.2 \pm 1.1$ \\
\hline \multirow[t]{5}{*}{ Flavour } & Cooked soy flour & $5.4 \pm 1.0$ & $5.9 \pm 1.0$ & $5.7 \pm 1.4$ \\
\hline & Toasted & $5.1 \pm 1.4$ & $5.9 \pm 1.0$ & $5.4 \pm 1.4$ \\
\hline & Overall flavour & $5.5^{\mathrm{a}} \pm 0.6$ & $6.1^{b} \pm 0.8$ & $5.6^{\mathrm{a}} \pm 0.9$ \\
\hline & Starchy & $1.8 \pm 1.0$ & $1.7 \pm 1.0$ & $1.5 \pm 0.9$ \\
\hline & Sour & $1.2 \pm 0.8$ & $1.2 \pm 0.9$ & $1.1 \pm 0.8$ \\
\hline \multirow[t]{3}{*}{ Mouthfeel } & Denseness & $5.6 \pm 1.2$ & $5.6 \pm 1.0$ & $5.5 \pm 1.1$ \\
\hline & Mealiness & $6.5 \pm 1.8$ & $6.5 \pm 1.7$ & $6.4 \pm 1.6$ \\
\hline & Grainy & $1.7 \pm 0.9$ & $1.7 \pm 0.9$ & $1.7 \pm 0.9$ \\
\hline \multirow[t]{4}{*}{ Post swallowing sensation } & Oily mouth coating & $5.0 \pm 2.2$ & $5.0 \pm 2.5$ & $4.9 \pm 2.4$ \\
\hline & Starchy aftertaste & $4.9 \pm 1.5$ & $4.5 \pm 1.5$ & $4.5 \pm 1.7$ \\
\hline & Cooked soy aftertaste & $3.8 \pm 1.4$ & $4.4 \pm 1.3$ & $4.5 \pm 1.5$ \\
\hline & Bitter aftertaste & $1.6 \pm 1.1$ & $1.5 \pm 1.1$ & $1.5 \pm 1.0$ \\
\hline
\end{tabular}

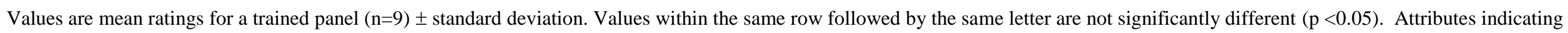
significant differences shown in bold.

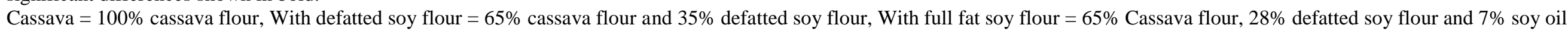

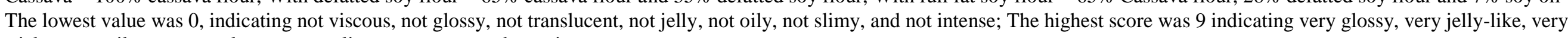
sticky, very oily, very translucent, very slimy very many and very intense

${ }^{1}$ Definitions of attributes are available in Table 1 
Table 4 shows the descriptive sensory analysis of extrusion cooked cassava-soy flour porridges. Considering appearance, glossiness and sliminess were rated high (5.9 to 6.4) while jelly-like and translucent were rated low (1.4 to 2.0) for all porridges. Translucency and jelly-like appearance were significantly more prominent in cassava porridge compared to the composited porridges. Flavour attributes of cooked soy flour, toasted nutty and overall flavour were rated high (5.4 to 5.9) while starchy flavour was of low intensity (1.5 to 1.8 ). Denseness and oily mouth coating were clearly observed in the three porridges but in a similar manner.

The panel identified clear differences between extrusion cooked porridges and the corresponding conventionally cooked porridges. For instance, despite containing 2.5 times more solids, extruded cassava porridge, porridge with defatted soy and porridge with full fat soy flour were less viscous by 1 to 3 scale units as compared to the corresponding conventionally cooked porridges. Jelly-like and translucent appearance was less prominent for all extrusion cooked porridges compared to the corresponding conventionally cooked porridges.

\section{Relating consumer liking to sensory attributes}

Ratings by individual consumers were mapped using PLS regression to evaluate interrelationships with sensory attributes (Figure 1A and 1B). The first two factors accounted for $87 \%$ of the $\mathrm{X}$ variance (sensory descriptors) and $39 \%$ of the $\mathrm{Y}$ variance (consumer ratings). The first factor and the second factor accounted for $69 \%$ and $18 \%$ of the $\mathrm{X}$ variance, respectively. Conventionally cooked porridges on the left side of the plot were characterised by grainy, sticky, translucent, jelly-like appearance, starchy aroma and bland flavour. 

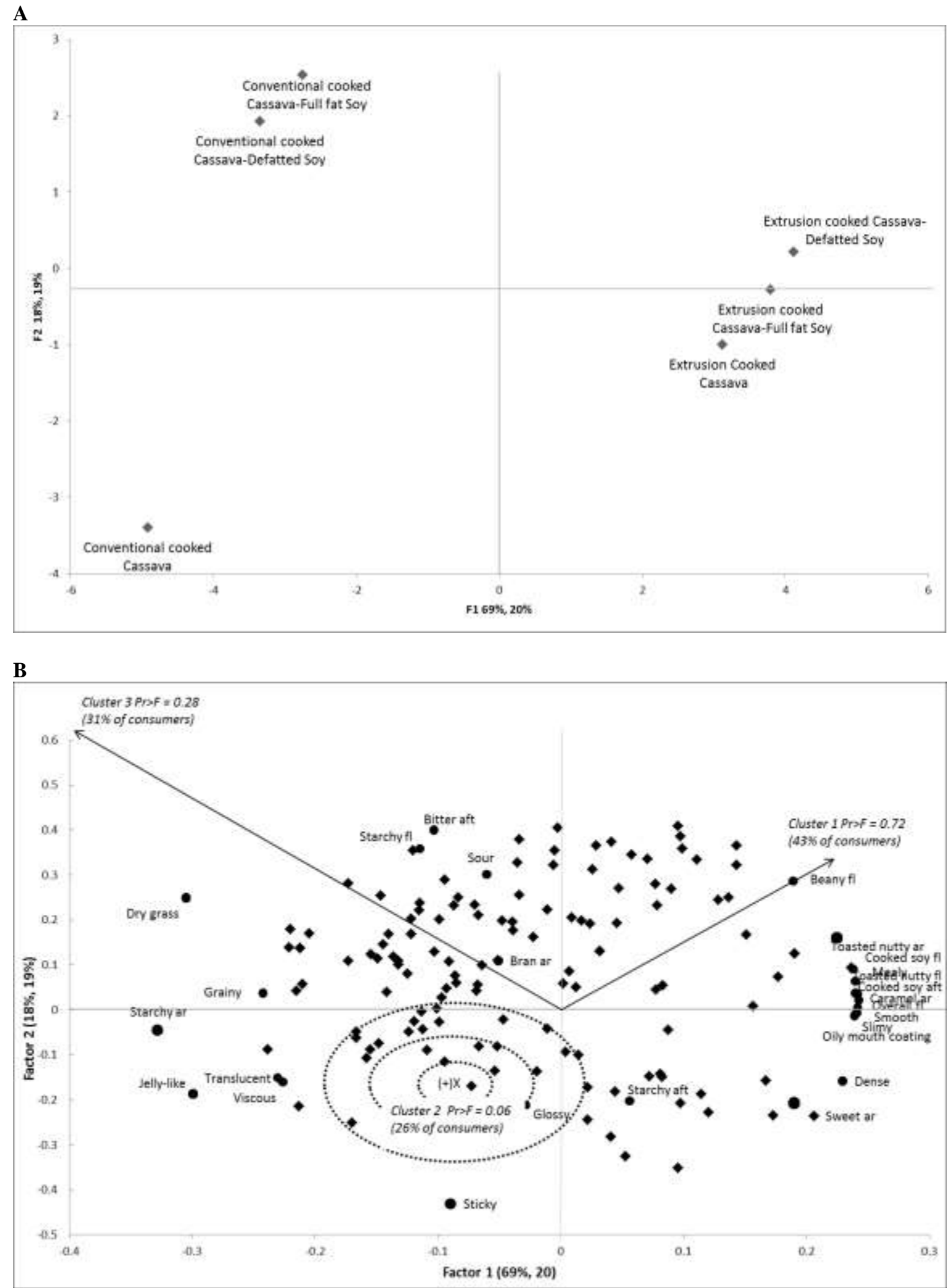

Fig 1: PLS Regression plots of factors 1 and 2 showing porridge (A) $\bullet$ sample scores and (B) $\bullet \mathrm{X}$ (descriptive sensory ratings) and $-\mathrm{Y}$ loadings for overall acceptability scores of consumers $(\mathrm{n}=122)$ with external preference mapping indicating direction of preference for three clusters of consumers. $a r=$ aroma, $\mathrm{fl}=$ flavour, aft $=$ aftertaste 
Extrusion cooked porridges on the right had more intense cooked soy flavour, toasted nutty flavour, higher overall flavour intensity, oily mouth coating and were denser.

Factor 1 explained $20 \%$ of the variance in consumer acceptance ratings. Factor 2 explained an additional $19 \%$ of the variance in consumer preferences. The directions of liking of porridges were identified for three clusters of consumers (Table 5). Vector models were the

Table 5: Ranks (1to 6) of the preference scores for consumers in the three clusters

\begin{tabular}{llccc}
\hline & & Cluster 1 & Cluster 2 & Cluster 3 \\
\hline Conventional (10\% solids) & Cassava & 1 & 3 & 4 \\
& With defatted soy & 2 & 5 & 5 \\
& With full fat soy & 3 & 4 & 6 \\
Extrusion cooked (25\% solids) & Cassava & 4 & 6 & 1 \\
& With defatted soy & 6 & 1 & 3 \\
& With full fat soy & 5 & 2 & 2 \\
\hline
\end{tabular}

best for clusters 1 and 3 although not significant. An ideal point circular model fitted the liking preference for Cluster 2 (26\% of consumers). Cluster 1, representing $43 \%$ of consumers, preferred conventionally cooked cassava porridge best with lowest preference for extrusion cooked cassava with defatted or full fat soy porridges. The preference of $31 \%$ of consumers (Cluster 3) was towards the conventionally cooked cassava soy porridges on the left of the plot.

\section{DISCUSSION}

Extrusion cooking allowed for 2.5 times more solids in porridge compared to conventionally cooked porridges, while maintaining a viscosity of 1000 to $3000 \mathrm{cP}$. This viscosity level is suitable for infant feeding ${ }^{11}$. Compositing allowed the functional addition of a rich protein 
source, soy that greatly increased the nutritional value of the porridges ${ }^{1}$. However, these improvements affected the sensory properties of the porridges.

Conventionally cooked porridges with soy flour had lower viscosity as compared to conventionally cooked porridges with only cassava flour. For young children to masticate and swallow complementary porridges of high energy density a low viscosity is required. Kayitesi et al. ${ }^{22}$ also reported lower porridge viscosity when sorghum flour was substituted with defatted heat treated high protein marama legume flour low in starch. Starch is the main component participating in gelatinization/pasting and viscosity development. Thus, reduction in viscosity when soy flour was added could be attributed to reduced amount of starch in the cassava-soy flour composite flour.

The sensory panel rated extrusion cooked porridges, at $25 \%$ solids, generally less viscous than conventionally cooked porridges ( $10 \%$ solids). For viscosity measurement, the panel used visual observation of resistance to flow when the porridge is stirred with a teaspoon. During normal porridge preparation, caregivers of infants use visual observation to judge the viscosity of porridges. The lower viscosity is advantageous for infant feeding and the extrusion cooked porridges with higher solids content are more nutrient dense than conventionally cooked porridges.

However, viscosity as measured by rheometer followed an inverse pattern compared to viscosity by the sensory panel. Ratings of denseness by the panel were similar to viscosity by rheometer. Note that the panel definition for denseness "the degree to which food feels heavy in the mouth and does not move easily" relates well to instrumental measurement of viscosity as applied in physical science; "a measure of a fluid's resistance to flow". 
Addition of full fat soy flour reduced stickiness in conventionally cooked porridge according to sensory panel and texture analysis. However, full fat soy flour in extrusion cooked porridges did not reduce stickiness. Others reported addition of $2 \%$ oil reduced the stickiness of sorghum couscous ${ }^{28}$. Decrease in swelling power and solubility of maize and potato starches with addition of glycerol monostearate has also been reported ${ }^{29}$. Addition of a lipid compound to wheat starch was suggested to increase the hydrophobicity of starch granules. Increased hydrophobicity lead to low water uptake and reduced granule swelling ${ }^{30}$. Possibly the reduced stickiness in the porridge with full fat soy flour could be due to reduced water uptake and granule swelling of starch. Furthermore, reduced amount of starch due to compositing could reduce the amount of starch that would cause porridges to be sticky.

Less sticky porridge would be beneficial for infant feeding because motor function of the tongue is underdeveloped until 2 years ${ }^{5}$, limiting manipulation of sticky food mass in the mouth. Furthermore, a less sticky porridge would be easier to handle by caregivers as the porridge stick less to the bowl and spoon.

Conventionally cooked porridges were less firm due to addition of soy flour as measured by texture analyser at $40{ }^{\circ} \mathrm{C}$. Gel firmness is mainly caused by retrogradation of starch gels and depends on the extent of the junction zone formation ${ }^{31}$. According to Ring et al. ${ }^{32}$ the initial firmness of starch gels during retrogradation is due to amylose matrix formation, the resulting firmness increase during storage due to crystallization of amylopectin. After porridge preparation, porridges were cooled for 20 min before textural measurements. Thus, textural properties should have been predominantly affected by the short term effects of amylose retrogradation. 
The relatively low firmness in the extrusion cooked porridges despite containing higher solids content could be because extrusion cooking caused depolymerization of amylopectin. According to Ozcan and Jackson ${ }^{33}$ degraded short amylopectin branches do not readily reassociate to form a gel network. Thus when extrusion cooked starch is pasted, the degraded molecules dissolve quickly and develop an initial viscosity but do not form a gel upon cooling. Porridges with low firmness are desirable for infant feeding because these porridges would have low viscosity at eating temperature $\left(\sim 40^{\circ} \mathrm{C}\right)$.

Conventionally cooked cassava porridge was more translucent compared to conventionally cooked composite porridges. Low starch paste clarity indicates the presence of swollen starch granules within gelatinized $\operatorname{starch}^{34}$. Sanchez et al. ${ }^{6}$ reported clarity of cooked cassava starch to be low (45.2\%) as measured using a spectrophotometer at $650 \mathrm{~nm}$ against a water blank. The relatively high translucency rating for cassava porridge could be attributed to low paste clarity since cassava flour contains $\sim 80 \% \operatorname{starch}^{6}$. Furthermore, a gelatinized starch suspension such as cassava porridge may be structurally considered as a three dimensional network of swollen starch granules embedded in a continuous phase of predominantly solubilized amylose molecules ${ }^{35}$. Addition of soy flour reduced translucency possibly by decreasing the amount of starch in the porridges. On the contrary, extrusion-cooked cassava porridge was less translucent because of starch depolymerisation through mechanical shearing at high temperature and low moisture ${ }^{36}$, which causes reduction of amylopectin to low molecular weight molecules ${ }^{37}$. This may explain why extrusion cooked cassava porridge was less translucent.

Caramel aroma and overall flavour of extrusion cooked porridges was more intense with noticeable toasted nutty flavour compared to conventionally cooked porridges. Flavour 
development could be due to Maillard reaction and oxidation of fatty acids (oleic, linoleic and linolenic acids) present in soy oil to produce furans, pyrazines and hexanal, respectively. In contrast, conventionally cooked porridges were characterized by bland starchy aroma and less intense overall flavour. Fadel and Faruok ${ }^{38}$ reported enhanced volatile compounds e.g. furans and pyrazines during heat treatment of maltose and alanine. Further, extrusion of starch in the presence of linoleic acid has been shown to form benzaldehyde and hexanal volatile compounds ${ }^{39}$.

Slightly more consumers preferred conventionally cooked porridges. This might be due to lack of familiarity with the sensory attributes related to extruded cassava porridges and soy composited porridges, which were new products to these consumers. Several studies have reported consumer preferences to be dependent on familiarity of stimuli ${ }^{40,41}$. Furthermore, the most familiar flavour is usually also the most preferred when consuming it for the first time in a test situation ${ }^{42}$.

While sensory attributes of extrusion cooked cassava-soy porridges might seem to be negative 'drivers' of liking when the porridges are consumed for the first time, these porridges were preferred by some of the consumers. It is possible that repeated exposure to the porridges may increase liking. A direct extrapolation of mothers' liking of the porridges to liking by infants (6-24 months) may not be a reliable or valid indication of acceptance by infants. The liking of the porridges by mothers could have been influenced by previous experiences and preconditioning related to the expected sensory attributes of porridges. Considering that complementary foods are the first foods introduced to an infant, infants' acceptance of foods is not preconditioned or dependent on previous experience ${ }^{43}$. Thus, although consumer liking was slightly lower for extrusion cooked cassava-soy flour 
porridges, there is a possibility that they will be accepted by infants. Furthermore, it is likely that positive marketing messages may enhance mothers' acceptance of extrusion cooked cassava-soy flour porridge, which is nutritionally optimized and does not involve lengthy preparation procedures.

\section{CONCLUSIONS}

Compositing cassava flour with full fat or defatted soy flour and extrusion cooking improves the textural properties of cassava porridge for better mastication and swallowing by infants. Compositing and extrusion cooking reduces the apparent negative attributes typical of conventionally cooked cassava porridge e.g. stickiness, high viscosity, translucent and jellylike appearance while increasing flavour intensity. Extrusion cooked cassava-soy porridges with $25 \%$ solids have viscosities within a range that is recommended for complementary feeding. However, slightly more consumers preferred conventionally cooked cassava only porridges. Thus, hedonic adjustment to the changed sensory properties of the extrusion cooked porridges in comparison to what mothers and caregivers are used to (conventionally cooked cassava only porridges) is required to ensure acceptance.

\section{ACKNOWLEDGEMENTS}

The International Institute of Tropical Agriculture, Mozambique is acknowledged for financial support and Bokomo Foods South Africa for assistance with extrusion of porridges. 


\section{REFERENCES}

1. Muoki PN, De Kock HL, and Emmambux NM, Effect of soy flour addition and heat-processing method on nutritional quality and consumer acceptability of cassava complementary porridges. $J$ Sci Food Agric. 92: 1771-1779 (2012).

2. Aloys N, and Ming Z, Traditional cassava foods in Burundi: A review. Food Res Int. 22: 1-27 (2006).

3. Muoki PN, and Maziya-Dixon B, Household utilization of manioc (Manihot esculenta Crantz) in Northern Mozambique. Ecol Food Nutr. 49: 337-356 (2010).

4. Nurfor FA, Walter WM, and Schwartz SJ, Emulsifiers affect the texture of pastes made from fermented and non-fermented cassava flours. Int J Food Sci Tech. 33: 455-460 (1998).

5. Sánchez T, Salcedo E, Ceballosa H, Dufoura D, Maflaam G, Morante N, Calle, F, Pérez JC, Debouck D, Jaramillo G, and Moreno IX. Screening of starch quality traits in cassava (Manihot esculenta Crantz). Starch/Stärke 61: 12-19 (2009).

6. Sajeeva MS, Moorthy SN, Kailappanb R, and Ranic VS, Gelatinisation characteristics of cassava starch settled in the presence of different chemicals. Starch/Stärke 55: 213-221 (2003).

7. Radhika SG, Shanavas S, and Moorthy SN, Influence of lipids isolated from soybean seed on different properties of cassava starch. Starch/Stärke 60: 485-492 (2008).

8. Chen CR, and Ramaswamy HS, Rheology of tapioca starch. Food Res Int. 32: 319-325 (1999).

9. Peroni FG, Rocha TS, and Franco CML, Some structural and physicochemical characteristics of tuber and root starches. Food Sci Tech Int. 12: 505-513 (2006).

10. Mosha AC, and Svanberg U, Preparation of weaning foods with high nutrient density using flour of germinated cereals. Food Nutr Bull. 5: 10-14 (1983).

11. Carruth BR, and Skinner JD, Feeding behaviours and other motor development in healthy children (224 months). J Am Coll Nutr. 21: 88-96 (2002).

12. Konstance RP, Omwulata CI, Smith PW, Lu, D, Tunick MH, Strang ED, and Holsinger VH, Nutrientbased corn and soy products by twin-screw extrusion. J Food Sci. 63: 1-5 (1998).

13. Rampersad R, Badrie N, and Comissiong E, Physico-chemical and sensory characteristics of flavored snacks from extruded cassava/pigeonpea flour. J Food Sci. 68: 363-367 (2003).

14. Fors SM and Eriksson CE, Pyrazines in extruded malt. J Sci Food Agri. 37: 991-1000 (1986).

15. Riha WE, Hwang C, Karwe MV, Hartman TG, and Ho, C-T, Effect of cysteine addition on the volatiles of extruded wheat flour. J Agric Food Chem. 44: 1847-1850 (1996). 
16. Madene A, Jacquot M, Scher J, and Desobry S, Flavour encapsulation and controlled release - A review. Int J Food Sci Tech. 41: 1-21 (2006)

17. Mustakas, GC, Full fat and defatted soy flour for human nutrition. J. Am. Oil Chem. Soc. 48: 815-819 (1971).

18. AACC, Approved Methods of the American Association of Cereal Chemists (10th edn). AACC International, St Paul, MN (2000).

19. Dziezoave NT, Graffham A, and Boateng EO, Training Manual for the Production of High Quality Cassava Flour [Online]. http//www.fao.org/teca/content/hugh quality-cassava-flour [11 September, 2010].

20. Bradbury HJ, Development of a sensitive picrate method to determine total cyanide and acetone cyanohydrin content in gari from cassava. Food Chem. 113:1329-1333 (2009).

21. FAO/WHO, FAO/WHO Food Standards Programme. Codex Alimentarius Commission XII (Suppl. 4). FAO, Rome (1991)

22. Kikafunda JK, Walker AF and Gilmour SG, Effect of refining and supplementation on the viscosity and energy density of weaning maize porridges. Int J Food Sci Nutr. 49:295-301 (1998).

23. Kayitesi E, Duodo GK, Minnaar A, and DeKock HL, Sensory quality of marama/sorghum composite porridges. J Sci Food Agric. 90: 2124-2132 (2010).

24. D'Silva TV, Taylor JRN, and Emmambux MN, Enhancement of the pasting properties of teff and maize starches through wet-heat processing with added stearic acid. J Cereal Sci. 53: 192-197 (2011).

25. Mezger TG, The rheology handbook for users of rotational and oscillatory rheometer. $2^{\text {nd }}$ revised edition. Vincentz Network GmbH \& Co KG: Hannover, pp 114-122 (2006).

26. Einstein MA, Descriptive techniques and their hybridization. In: Sensory Science Theory and Applications in Foods. Lawless HT, and Klein BP, (Eds). Marcel Dekker: New York, pp 317-338 (1991).

27. Liu H, Xu XM, and Guo SD, Rheological, texture and sensory properties of low-fat mayonnaise with different fat mimetics. LebensmWiss Technol. 40: 946-954 (2007).

28. Aboubacar A, and Hamaker BR, Low molecular weight soluble starch and its relationship with sorghum couscous stickiness. J Cereal Sci. 31: 119-126 (2000).

29. Kuar K, and Singh J, Amylose-lipid complex formation during cooking of rice flour. Food Chem. 71: 511-517 (2000). 
30. Richardson G, Langton M, Bark A, and Hermansson AM, Wheat starch gelatinization - the effects of sucrose, emulsifier and the physical state of the emulsifier. Starch/Stärke 55: 150-161 (2003).

31. Miles MJ, Morris VJ, Orford PD, and Ring SG, The role of amylose and amylopectin in the gelation and retrogradation of starch. Carbohydr Res. 135: 271-281 (1985).

32. Ring SG, Colonna P, Kenneth JI, Kalichersky TM, Miles MJ, Morris VJ, and Orford PD, The gelation and crystallisation of amylopectin. Carbohydr Res. 162: 277-293 (1987).

33. Ozcan S, and Jackson DS, Functionality behavior of raw and extruded corn starch mixtures. Cereal Chem. 82: 223-227 (2005).

34. Craig SAS, Maringat CC, Seib PA, and Hoseney RC, Starch paste clarity. Cereal Chem. 66: 173-182 (1989).

35. Ojijo NKO, and Shimoni, E, Rheological properties of fermented finger millet. (Eleucine coracana) thin porridge. Carbohydr Polym. 57: 135-143 (2004).

36. Harper JM, Food extruders and their applications In: Extrusion Cooking; Mercier C, Linko P, Harper JM, (Eds); American Association of Cereal Chemists: St. Paul, MN (1989).

37. Liu C, Halley PJ, and Gilbert RG, Mechanism of degradation of starch, a highly branched polymer during extrusion. Macromolecules 43: 2855-2864 (2010).

38. Fadel HHM, and Farouk A, Caramelization of maltose solution in presence of alanine. Amino Acids 22: 199-213 (2002).

39. Solina M, Johnson RL, and Whitfield FB, Effect of glucose and hydrolysed vegetable protein on the volatile components of extruded wheat starch. Food Chem. 100: 678-692 (2007).

40. Hetherington MM, Bell A, and Rolls BJ, Effects of repeat consumption on pleasantness, preference and intake. Br Food J. 102: 507-521 (2000).

41. Stallberg-White C, and Pliner P, The effect of flavour principles on willingness to taste novel foods. Appetite 33: 209-221 (1999).

42. Porcherot C, and Issanchau S, Dynamics of liking for flavoured crackers. Test of predictive value of a boredom test. Food Qual Prefer. 9: 21-29 (1998).

43. Nicklaus S, Boggio V, Chabanet $\mathrm{C}$, and Issanchou S, A prospective study of food preferences in childhood. Food Qual Prefer. 15: 805-818 (2004). 